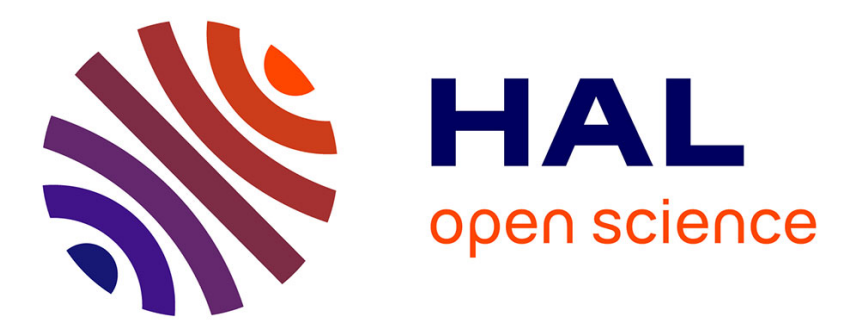

\title{
From 1,4-Disaccharide to 1,3-Glycosyl Carbasugar: Synthesis of a Bespoke Inhibitor of Family GH99 Endo- $\alpha$-mannosidase
}

Dan Lu, Sha Zhu, Lukasz Sobala, Ganeko Bernardo-Seisdedos, Oscar Millet, Yongmin Zhang, Jesus Jimenez-Barbero, Gideon Davies, Matthieu Sollogoub

\section{To cite this version:}

Dan Lu, Sha Zhu, Lukasz Sobala, Ganeko Bernardo-Seisdedos, Oscar Millet, et al.. From 1,4Disaccharide to 1,3-Glycosyl Carbasugar: Synthesis of a Bespoke Inhibitor of Family GH99 Endo$\alpha$-mannosidase. Organic Letters, 2018, 20 (23), pp.7488-7492. 10.1021/acs.orglett.8b03260 . hal02292793

\section{HAL Id: hal-02292793 https: / hal.sorbonne-universite.fr/hal-02292793}

Submitted on 20 Sep 2019

HAL is a multi-disciplinary open access archive for the deposit and dissemination of scientific research documents, whether they are published or not. The documents may come from teaching and research institutions in France or abroad, or from public or private research centers.
L'archive ouverte pluridisciplinaire HAL, est destinée au dépôt et à la diffusion de documents scientifiques de niveau recherche, publiés ou non, émanant des établissements d'enseignement et de recherche français ou étrangers, des laboratoires publics ou privés. 


\title{
From 1,4-Disaccharide to 1,3-Glycosyl-Carbasugar: Synthesis of a Bespoke Inhibitor of Family GH99 Endo- $\alpha$-Mannosidase
}

\author{
Dan Lu, ${ }^{\mathrm{a} \ddagger}$ Sha Zhu, ${ }^{\mathrm{a} \ddagger}$ Lukasz F. Sobala, ${ }^{\mathrm{b}}$ Ganeko Bernardo-Seisdedos, ${ }^{\mathrm{c}}$ Oscar Millet, ${ }^{\mathrm{c}}$ Yongmin Zhang, ${ }^{\mathrm{a}}$ Jesus Jiménez- \\ Barbero, ${ }^{\mathrm{d}, \mathrm{e}}$ Gideon J. Davies, ${ }^{\mathrm{b}}$ Matthieu Sollogoub ${ }^{\mathrm{a}, *}$ \\ ${ }^{a}$ Sorbonne Université, CNRS, Institut Parisien de Chimie Moléculaire, UMR 8232, 4 place Jussieu, 75005 Paris, France \\ ${ }^{b}$ York Structural Biology Laboratory, Department of Chemistry, University of York YO1O 5DD, U.K. \\ ${ }^{c}$ Protein Stability and Inherited Diseases Laboratory, CIC bioGUNE, Bizkaia Technology Park, Building 800, 48160 Derio, \\ Spain \\ ${ }^{d}$ Molecular Recognition and Host-Pathogen Interactions, CIC bioGUNE, Bizkaia Technology Park, Building 800,48160 \\ Derio, Spain \\ e Ikerbasque, Basque Foundation for Science, Maria Diaz de Haro 3, 48013 Bilbao, Spain
}

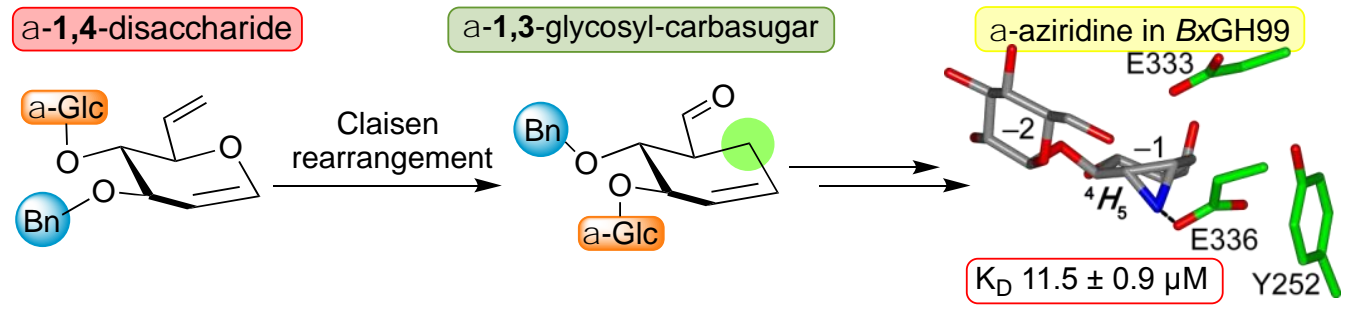

\begin{abstract}
Understanding of enzyme reaction mechanism can lead to the design of enzyme inhibitors. A Claisen rearrangement was used to allow the conversion of an $\alpha-1,4$ disaccharide into an $\alpha$-1,3-linked glycosylcarbasugar to target the endo- $\alpha$-mannosidase from glycosidase family GH99 which, unusually, is believed to act through a 1,2 anhydrosugar "epoxide" intermediate. Using NMR and X-ray crystallography, it is shown that glucosylcarbasugar- $\alpha$-aziridines can act as reasonably potent endo- $\alpha$-mannosidase inhibitors, likely by virtue of their shape-mimicry and the interactions of the aziridine nitrogen with the conserved catalytic acid/base of the enzyme active-site.
\end{abstract}

Understanding enzyme reaction mechanisms is essential for the rational design of inhibitors. Glycoside hydrolases $(\mathrm{GH})$, also called glycosidases, are a vast group of enzymes that are classified, based upon their amino-acid sequence similarity, into over 150 distinct families in the Carbohydrate Active Enzymes database (CAZy). ${ }^{1,2}$ The vast majority of these enzymes can be divided into two classes according to their reaction mechanism and the relative configuration of substrate and product: those that act with retention or inversion of anomeric configuration. The retaining glycosidases utilize a double nucleophilic displacement which results in net retention of configuration at the anomeric center. The retaining reaction classically involves nucleophilic amino-acid side-chain and proceeds via a covalent glycosyl-enzyme intermediate. Some enzymes also use neighboring group participation reactions (notably those active on beta linked GlcNAc). ${ }^{3}$ Recently, a new neighbouring-group retaining mechanism involving an intermediate epoxide and hence no covalent bond to the enzyme was proposed for endo- $\alpha$-mannosidases and endomannanases ( $\alpha$-Glc-1,3- $\alpha$-Man-OR and $\alpha$-Man-1,3- $\alpha$ Man-OR substrates) of the GH99 family. ${ }^{4,5}$ In this putative mechanism, nucleophilic attack by the manno-O2 atom, allows catalysis via a 1,2 anhydro sugar "epoxide" intermediate. (Scheme 1). In terms of shape and charge changes, a positive charge is very likely to be developed and the conformation of the pyranose changes from ${ }^{4} C_{1}$ of the substrate to the ${ }^{4} E /{ }^{4} H_{5}$ of the epoxide. Based on these considerations, inhibitors that have been designed for this important class of enzymes ${ }^{6}$ are $\alpha-1,3$-disaccharide analogues and these fall into two categories: those which mimic the charge and those which mimic its shape. In the first class, we find the usual deoxymannojirimycin (1), isofagomine (2) or noeuromycin derivatives. ${ }^{4,7}$ A clear influence of the amine position has been demonstrated. It has also been shown that the glucal derivative $\mathbf{3}$ is an inhibitor of the enzyme due to its shape, which corresponds to a ${ }^{4} H_{5}$ conformation. ${ }^{7}$ Here, we decided to combine both properties in 
a new inhibitor and create an amine with a likely ${ }^{4} \mathrm{E} /{ }^{4} \mathrm{H}_{5}$ conformation. To achieve both the half-chair conformation and introduce an amino group, we decided to synthesize an aziridine on a carbasugar for obvious stability reason. Furthermore, according to the mechanism, the catalytic acid E336 of Bacteroides xylanisolvens GH99 (BxGH99) should be in its acidic form and therefore prone to release a proton to the aziridine, hence we decided to investigate the synthesis and inhibitory ability of glucosyl-carbasugar- $\alpha$-aziridine 4. (Scheme 1)

There are many ways to synthesize carbasugars,${ }^{8}$ including those containing a disaccharide motif. ${ }^{9}$ The most direct way would be to start directly from the corresponding disaccharide, ${ }^{10}$ but the necessary 1,3-disaccharides (like Glc- $\alpha-1,3$ Glc) are rare and expensive. The synthesis of the two monosaccharides and their subsequent assembly seemed tedious. We therefore decided to use a trick based on the use of Claisen rearrangement to make carbasugars nicely developed by Nagarajan on monosaccharides. ${ }^{11}$ In this reaction, a glucal functionalized with an alkene in position 6 affords a carba-glucal with an aldehyde in position 6 . This is due to the symmetry of the molecule, and in the operation, the protecting group in position 4 becomes the one in position 3 in the new numbering of the carbasugar. (Scheme 2)

This approach was used to synthesize a 1,3-pseudodisaccharide from a 1,4-disaccharide. The synthesis would start from maltose, that would be converted into the doubly unsaturated maltal 5, which in turn could undergo Claisen rearrangement to give keto-alkene $\mathbf{6}$. This operation is key to the total synthesis as we not only obtain the desired 1,3pseudo-disaccharide but also the alkene which will be converted into the desired epoxide 7 and aziridine 4. (Scheme 3)

Scheme 2. Claisen rearrangement leading to interchange of position 3 and 4 from the glucal to the carba-glucal.
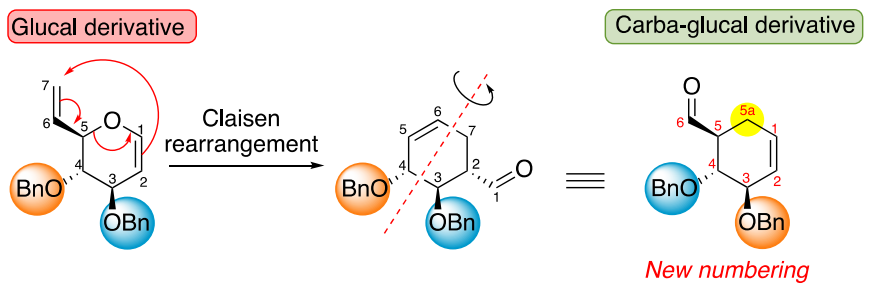

Scheme 1. Postulated enzymatic hydrolytic mechanism for Bacteroides xylanisolvens GH99 (BxGH99), in which catalysis occurs through a 1,2 anhydrosugar intermediate (top). Known, and designed (this work) substrate analogues (below) Residue numbering as in BxGH99.
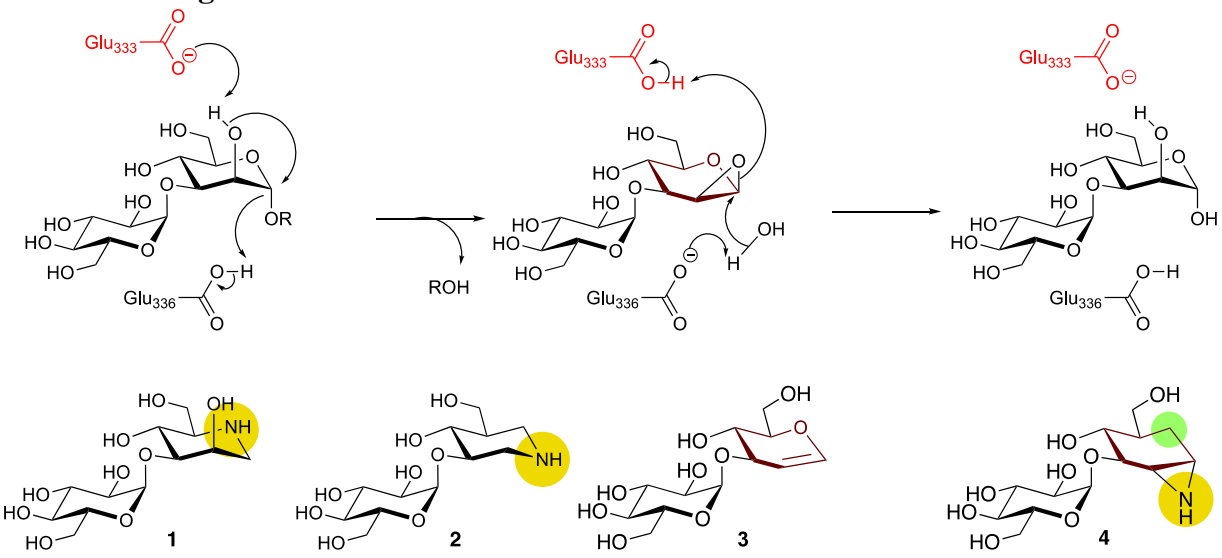

Charge mimicry

Scheme 3. Retrosynthetic analysis for the synthesis of aziridine 4.

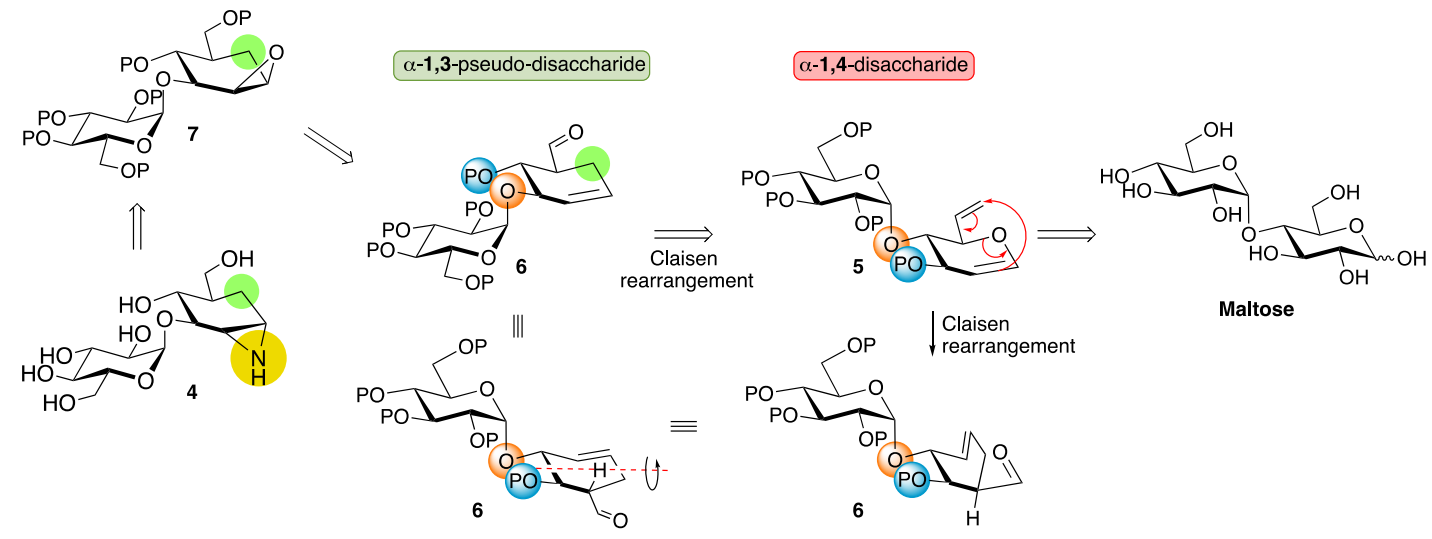


Maltal was prepared according to Haworth, ${ }^{12}$ with a slight modification in the deprotection step (see SI). Next, the differentiation of the two primary hydroxyl groups was required. For this, we decided to protect the glucoside with a benzylidene group. This reaction had to be performed with great care (Scheme 4) by controlling the amount of camphor sulfonic acid used (0.1 equiv). Then, the other primary alcohol could be selectively silylated, subsequent benzylation and de-silylation afforded the alcohol 8. Oxidation using Dess-Martin periodinane (DMP) followed by olefination produced dialkene 9. Claisen rearrangement on 9 was performed under micro-wave irradiation at $240{ }^{\circ} \mathrm{C}$ and was immediately followed by the aldehyde reduction to afford alcohol $\mathbf{1 0}$ in $76 \%$ yield. (Scheme 4)

Scheme 4. Key Claisen rearrangement and preparation of the substrate 10.
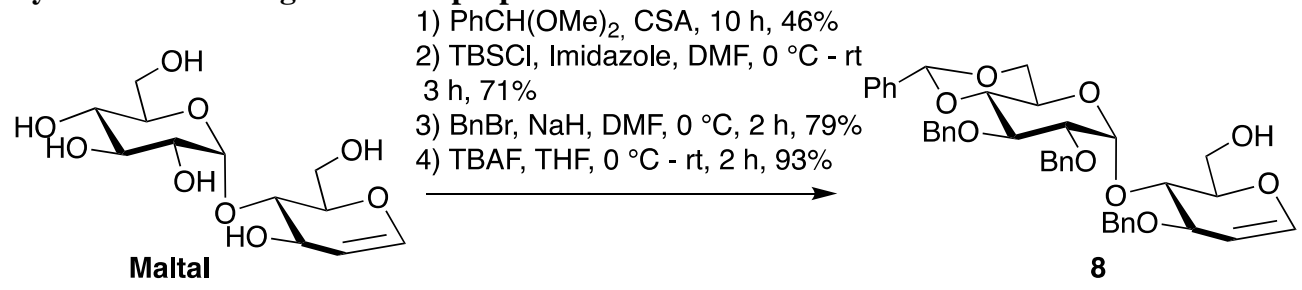

1) $\mathrm{CH}_{2} \mathrm{Cl}_{2}$, rt, $3 \mathrm{~h}$

2) $\mathrm{KHMDS}, \mathrm{PPh}_{3} \mathrm{CH}_{3} \mathrm{I}$

$\mathrm{THF},-78^{\circ} \mathrm{C}, \mathrm{rt}, 3 \mathrm{~h}$
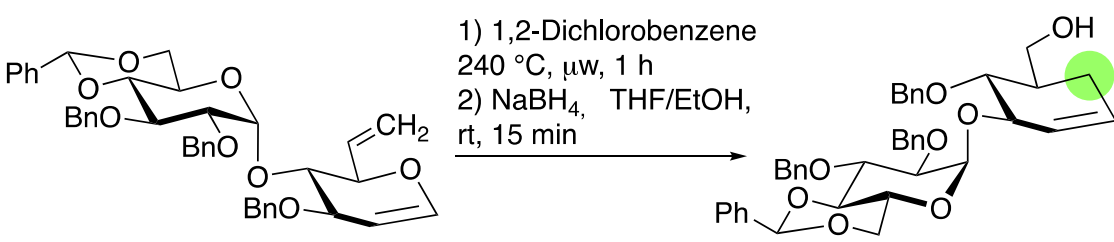

$9(71 \%, 2$ steps $)$

$10(76 \%, 2$ steps $)$

\section{Scheme 5. Synthesis of aziridine carbasugars 4.}

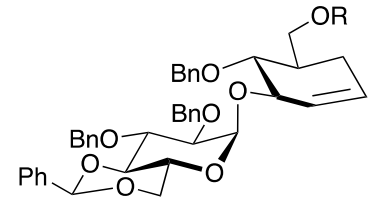

$\mathrm{BnBr}, \mathrm{NaH}$ DMF, $75 \%$

$11, R=B n$

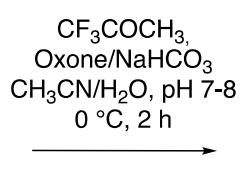

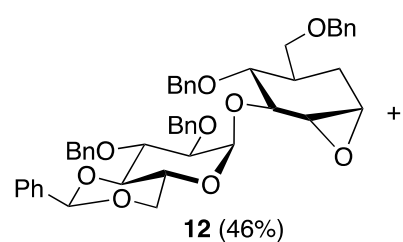

$12(46 \%)$

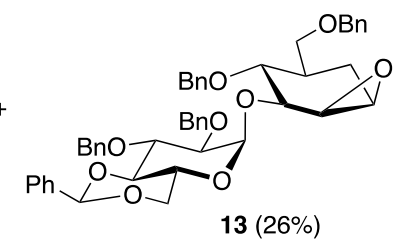

$13(26 \%)$

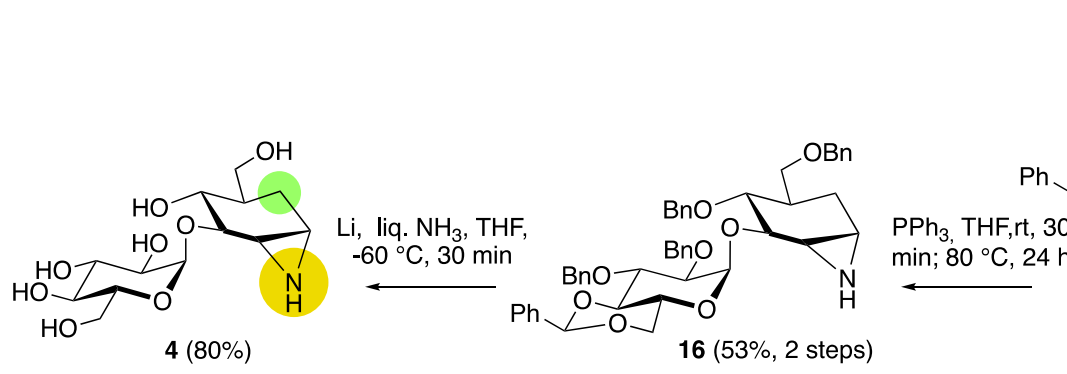

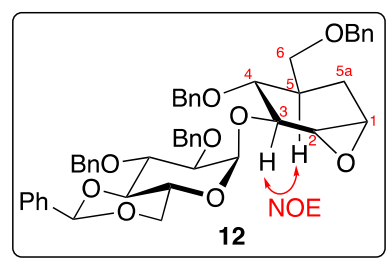

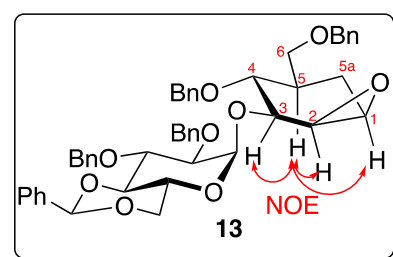

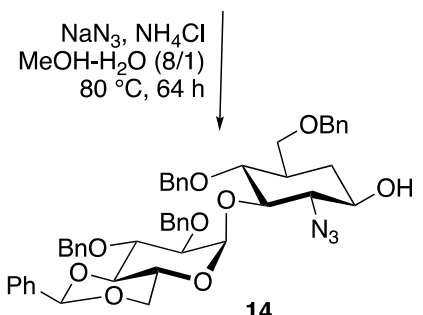

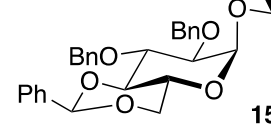

epoxidation, azide-ring opening, and Staudinger azidereduction-aziridination; ${ }^{13}$ this strategy also operates with overall inversion of configuration of the three-membered ring. We first benzylated the remaining hydroxyl in $\mathbf{1 0}$ to

With the alkene $\mathbf{1 0}$ in hand, we investigated its aziridination. We opted for a three-step route: 
give 11, which was epoxidized using methyl(trifluoromethyl)dioxirane generated in situ ${ }^{14}$ to give the $\alpha$-epoxide $\mathbf{1 2}$ in $46 \%$ yield and the $\beta$-epoxide $\mathbf{1 3}$ in $26 \%$ yield, which were separated by silica gel flash chromatography. The stereochemistry of these epoxides was determined thanks to a NOESY experiment. $\alpha$-Epoxide 12 displayed cross correlations between $\mathrm{H}-5$ and $\mathrm{H}-3$, while in $\beta$-epoxide $13 \mathrm{H}-5$ showed cross-correlations with $\mathrm{H}-3$ but also with $\mathrm{H}-1$ and $\mathrm{H}-2$ (Scheme 5 and SI). This reaction therefore produced the undesired $\alpha$-epoxide as the major product, but all our attempts to improve the situation with various epoxidation reactions gave lower yields. For instance, mCPBA which was previously often used to synthesize epoxides from cyclohexenes polyols ${ }^{15}$ did not improve the selectivity nor the yield. Further treatment of the isolated epoxide $\mathbf{1 3}$ with sodium azide furnished a mixture of 1,2-trans azido alcohols 14/15, which under the action of $\mathrm{PPh}_{3}$ afforded $\alpha$-aziridine 16 in $52 \%$ yield after these two steps. Final deprotection, using Birch conditions, ${ }^{16}$ afforded the unprotected aziridinated pseudo-sugar 4 (Scheme 5).

The properties of aziridine 4 were investigated with GH99 family members Bt (Bacteorides thetaiotaomicron) and $B x \mathrm{GH} 99$. A crystal structure of the BxGH99 enzyme in complex with the aziridine 4 at a resolution of $1.27 \AA$ (PDB accession: 6HMG) was obtained by soaking of
$B x \mathrm{GH} 99$ crystals with an aqueous solution of the compound. The nitrogen atom of the aziridine makes a $2.6 \AA$ hydrogen bond with one of the side chain oxygen atoms of $B x \mathrm{GH} 99$ residue E336, which acts as an acid/base in the proposed GH99 mechanism (Scheme 1). In a ternary complex with the aziridine and $\alpha-1,2$-mannobiose (obtained at a resolution of $1.03 \AA$, PDB $6 \mathbf{H M H}$ ), this distance changes to $2.7 \AA$. The interaction is shown in Figure 1A. In both cases, the pseudopyranose ring is in a ${ }^{4} H_{5}$ conformation, as predicted for the azirdine and likely resembles the intermediate/transition-state of the reaction. Indeed, it binds similarly to ManGlucal and GlcChex ${ }^{17}$ (Figure 1B), which was also observed in a ${ }^{4} H_{5}$ conformation in complex with $B x$ GH99 (PDB 5M5D and 5MC8). ${ }^{7}$

Using NMR we have determined the dissociation constant $\left(K_{\mathrm{D}}\right)$ of the aziridine with ${ }^{15} \mathrm{~N}$-labelled $B t \mathrm{GH} 99$ to be 11.5 $\pm 0.9 \mu \mathrm{M}$ (Figure 1C). The compound, therefore, binds to BtGH99 with an affinity 2-fold higher than GlcDMJ $(24 \mu \mathrm{M})$ and slightly higher than ManGlucal $(15 \mu \mathrm{M})$. However, it is not a potent inhibitor in comparison with GlcIFG, ManIFG or ManNOE, all of which bind to $B t \mathrm{GH} 99$ with a $K_{\mathrm{D}}$ in the nanomolar range. ${ }^{7}$

Figure 1. (A) Divergent stereo ("wall-eyed") view of 4 in complex with BxGH99. Catalytic residues surrounding the -1 subsite and the interaction between the aziridine $\mathrm{N}$ and $\mathrm{E336} O \varepsilon$ are shown. The $2 \mathrm{~m} F_{0}-\mathrm{DF} F_{\mathrm{c}}$ synthesis contoured at $1 \mathrm{e}^{-} / \AA^{3}$. (B) Comparison of the ligands observed in the ${ }^{4} \mathrm{H}_{5}$ conformation in complex with BxGH99. ${ }^{7}$ Green: the aziridine 4, gold: ManGlucal (from PDB 5M5D), grey: GlcChex (from PDB 5MEL). The sugar moiety in the -2 subsite is not shown. (C) The result of NMR titration of $B t \mathrm{GH} 99$ with 4 . The protein concentration in the solution was $58 \mu \mathrm{M}$. 
In conclusion, we have devised a strategy to synthesize 1,3-glycosyl-carbasugars designed to interact with the family GH99 endo- $\alpha$-mannosidases. The obtained inhibitor has improved activity in comparison with the shape mimics, but does not reach the affinity of isofagomine or noeuromycin analogues. This probably indicates that the aziridine is not charged owing to its lower $\mathrm{pKa}$. In future work, we will be able to use this synthetic strategy to synthesize other analogues to study the mechanism of this family of glycosidases which is not yet firmly established.

\section{ASSOCIATED CONTENT}

\section{Supporting Information}

Experimental details, spectra and X-ray crystallography. The Supporting Information is available free of charge on the ACS Publications website.

\section{AUTHOR INFORMATION}

\section{Corresponding Author}

* E-mail: matthieu.sollogoub@sorbonne-universite.fr

\section{Author Contributions}

All authors have given approval to the final version of the manuscript. / \$These authors contributed equally.

\section{ACKNOWLEDGMENT}

We thank Chinese Scholarship Council (CSC).

\section{REFERENCES}

(1) http://www.cazy.org/

(2) Lombard, V.; Golaconda Ramulu, H.; Drula, E.; Coutinho, P. M.; Henrissat B. Nucleic Acids Res. 2014, 42, D490.

(3) (a) Macauley, M. S.; Whitworth, G. E.; Debowski, A. W.; Chin, D.; Vocadlo, D. J. J. Biol. Chem. 2005, 280, 25313. (b) Vocadlo, D. J.; Davies, G. J. Curr. Opin. Chem. Biol. 2008, 12, 539. (c) Marcelo, F.; He, Y.; Yuzwa, S. A.; Nieto, L.; Jiménez-Barbero, J.; Sollogoub, M.; Vocadlo, D. J.; Davies, G. D.; Blériot, Y. J. Am. Chem. Soc. 2009, 131, 5390 .

(4) Thompson, A. J.; Williams, R. J.; Hakki, Z.; Alonzi, D. S.; Wennekes, T.; Gloster, T. M.; Songsrirote, K.; Thomas-Oates, J. E.; Wrodnigg, T. M.; Spreitz, J.; Stutz, A. E.; Butters, T. D.; Williams, S. J.; Davies, G. J. Proc. Natl. Acad. Sci. USA 2012, 109, 781.

(5) Hakki, Z.; Thompson, A. J.; Bellmaine, S.; Speciale, G.; Davies, G. J.; Williams, S. J. Chem. Eur. J. 2015, 21, 1966

(6) (a) Lubas, W. A.; Spiro, R. G. J. Biol. Chem. 1987, 262, 3775; Lubas, W. A.; Spiro, R. G. J. Biol. Chem. 1988, 263, 3990. (b) Moore, S. E.; Spiro, R. G. J. Biol. Chem. 1990, 265, 13104. (c) Moore, S. E.; Spiro, R. G. J. Biol. Chem. 1992, 267, 8443. (d) Hiraizumi, S.; Spohr, U.; Spiro, R. G. J. Biol. Chem. 1993, 268, 9927 (e) Hakki, Z.; Thompson, A. J.; Bellmaine, S.; Speciale, G.; Davies, G. J.; Williams, S. J. Chem. Eur. J. 2015, 21, 1966. (f) Cuskin, F.; Lowe, E. C.; Temple, M. J.; Zhu, Y.; Cameron, E. A.; Pudlo, N. A.; Porter, N. T.; Urs, K.; Thompson, A. J.; Cartmell, A.; Rogowski, A.; Hamilton, B. S.; Chen, R.; Tolbert, T. J.; Piens, K.; Bracke, D.; Vervecken, W.; Hakki, Z.; Speciale, G.; Munoz-Munoz,
J. L.; Day, A.; Pena, M. J.; McLean, R.; Suits, M. D.; Boraston, A. B.; Atherly, T.; Ziemer, C. J.; Williams, S. J.; Davies, G. J.; Abbott, D. W.; Martens, E. C.; Gilbert, H. J. Nature 2015, 517, 165.

(7) Petricevic, M.; Sobala, L. F.; Fernandes, P. Z.; Raich, L.; Thompson, A. J.; Bernardo-Seisdedos, G.; Millet, O.; Zhu, S.; Sollogoub, M.; Jimenez-Barbero, J.; Rovira, C.; Davies, G. J.; Williams, S. J. J. Am. Chem. Soc. 2017, 139, 1089.

(8) (a) Sollogoub, M., Sinaÿ P. in The Organic Chemistry of Sugars (Ed.: D. E. Levy, P. Fugedi), CRC Press, Boca Raton, 2006, ch. 8, pp. 349; Kobayashi Y. (2008) Carbasugars: Synthesis and Functions. In: Fraser-Reid B.O., Tatsuta K., Thiem J. (eds) Glycoscience. Springer, Berlin, Heidelberg. (b) Arjona, O., Gomez, A. M., Lopez, J. C.; Plumet, J. Chem. Rev. 2007, 107, 1919. (c) Shing, T. K. M.; Kwong, C. S. K.; Cheung, A. W. C.; Kok, S. H.-L.; Yu, Z.; Li, J.; Cheng, C. H. K. J. Am. Chem. Soc. 2004, 126, 15990. (d) Shing, T. K. M.; Cheng, H. M. J. Org. Chem. 2007, 72, 6610.

(9) (a) Suami, T.; Ogawa, S. Adv. Carbohydr. Chem. Biochem. 1990, 48, 21. (b) Ogawa, S.; Matsunaga, N.; Palcic, M. M. Carbohydr. Lett. 1997, 2, 299 (c) Ogawa, S.; Furuya, T.; Tsunoda, H.; Hindsgaul, O.; Stangier, K.; Palcic, M. M. Carbohydr. Res. 1995, 271, 197 (d) Pearce, A. J.; Sollogoub, M.; Mallet, J.-M.; Sinaÿ, P. Eur. J. Org. Chem. 1999, 2103 (e) López-Méndez, B.; Jia, C.; Zhang, Y.; Sinaÿ, P.; Zhang, L.-H.; Jiménez-Barbero, J.; Sollogoub, M. Chem. Asian J. 2008, 3, 51. (f) Xu, B.; Unione, L.; Sardinha, J.; Wu, S.; Ethève-Quelquejeu, M.; Pilar Rauter, A.; Blériot, Y.; Zhang, Y.; Martín-Santamaría, S.; Diaz, D.; JiménezBarbero, J.; Sollogoub, M. Angew. Chem. Int. Ed. 2014, 53, 9597. (10) Spreitz, J.; Stütz, A. E. Carbohydr. Res. 2004, 339, 1823.

(11) Sudha, A. V. R. L.; Nagarajan, M. J. Chem. Soc., Chem. Commun. 1998, 925.

(12) Haworth, W. N.; Hirst, E. L.; Reynol, R. J. W. J. Chem. Soc., 1934, 302.

(13) (a) Pöchlauer, P.; Müller, E. P.; Peringer, P. Helv. Chim. Acta 1984, 67, 1238. (b) Legters, J.; Thijs, L.; Zwanenburg, B. Tetrahedron Lett. 1989, 30, 4881 (c) P. Crotti, V. Di Bussolo, L. Favero, M. Pineschi, Tetrahedron 1997, 53, 1417; Pulipaka, A. B.; Bergmeier, S. C. Synthesis 2008, 1420.

(14) (a)Yang, D.; Wong, M. K.; Yip, Y. C. J. Org. Chem. 1995, 60, 3887. (b) Shu, L. H.; Shi, Y. J. Org. Chem. 2000, 65, 8807.

(15) (a) Ogawa, S.; Tonegawa, T. Carbohydr. Res. 1990, $204,51$. (b) Ogawa, S.; Tonegawa, T.; Nishi, K.; Yokoyama, J. Carbohydr. Res. 1992, 229, 173 (c) Tai, V. W. F.; Fung, P. H.; Wong, Y. S.; Shing, T. K. M. Tetrahedron-Asymmetry 1994, 5, 1353. (d) Gonzalez-Bulnes, P.; Casas, J.; Delgado, A.; Llebaria, A. Carbohydr. Res. 2007, 342, 1947 (e) D'Antona, N.; Morrone, R.; Bovicelli, P.; Gambera, G.; Kubac, D.; Martinkova, L. TetrahedronAsymmetry 2010, 21, 2448.

(16) Kallemeijn, W. W.; Li, K. Y.; Witte, M. D.; Marques, A. R. A.; Aten, J.; Scheij, S.; Jiang, J. B.; Willems, L. I.; Voorn-Brouwer, T. M.; van Roomen, C. P. A. A.; Ottenhoff, R.; Boot, R. G.; van den Elst, H.; Walvoort, M. T. C.; Florea, B. I.; Codée, J. D. C.; van der Marel, G. A.; Aerts, J. M. F. G.; Overkleeft, H. S. Angew. Chem. Int. Ed. 2012, 51, 12529.

(17) GlcChex was synthesized by full deprotection of compound $\mathbf{1 0}$, using $\mathrm{Li} / \mathrm{NH}_{3}$, and previously disclosed in reference 7 . 